\title{
Outcomes of operative versus non-operative interventions on rectus abdominis diastasis: a combination of a retrospective analysis and a systematic review
}

sue yuan ( $\sim$ ldyse2018@csu.edu.cn )

Xiangya Hospital Central South University https://orcid.org/0000-0001-7120-4869

Yunxia Li

Xiangya Hospital Central South University

Qi Li

Central South University Xiangya School of Nursing

Lu Fan

Central South University Xiangya School of Nursing

Jie Zhou

Brigham and Women's Hospital Department of Anesthesiology Perioperative and Pain Medicine

Research article

Keywords: Rectus abdominis diastasis; recurrence rate; hernia; adverse events; mesh; strain of muscle, fascial and tendon

Posted Date: December 17th, 2019

DOI: https://doi.org/10.21203/rs.2.18930/v1

License: (9) This work is licensed under a Creative Commons Attribution 4.0 International License. Read Full License 


\section{Abstract}

Background There is no current consensus on the treatment of Rectus abdominis diastasis (RAD). This study aimed to assess the recurrence rates and adverse events after operative or non-operative intervention.Methods We performed a retrospective study and a systematic review. Patients with a diagnosis of RAD who underwent the mesh placement procedure were eligible. Data were collected from The Research Patient Data Registry. Then, a systematic literature search of Pubmed, Embase, and The Cochrane Library databases was performed. A modified Downs and Black checklist for randomized and non-randomized studies of healthcare interventions (DB) was used to evaluate the methodological quality of the studies.Results Data of 82 patients was collected. The 5-year cumulative incidence of recurrence of abdominal hernia was high (females $37.0 \%$ vs males $43.4 \%, P=0.557$ ). Of 3908 citations, 27 studies describing 2,372 patients were included into the systematic review. In non-operative group, seven studies (25.93\%) with a total of 603 subjects reported no patient relapsed after a follow-up of 12 months; a $40 \%$ recurrence rate was reported after a follow-up of 5 years in one study, the adverse events associated with operation mainly included seroma (5.13\%), a sensibility disorder of the abdominal skin (2.26\%), and minor scarring (1.56\%). Muscle strength training, such as training of the pelvic floor muscles, abdominal muscles, rectus abdominis, internal/external oblique, or transverse abdominal muscles, was performed in all included non-surgery studies, neither adverse events nor recurrence was reported.Conclusion Operative intervention may be effective at restoring the functions of the rectus muscles and at improving the stability of abdominal wall in the short-term, while non-operative intervention has a limited effect, especially for those RAD combined with hernia.

\section{Background}

Rectus abdominis diastasis (RAD) is characterized by widening of the linea alba and usually presenting with a "bulge" in the midline when intra-abdominal pressure is increased. This phenomenon at present was well-recognized as the laxity of the ventral abdominal musculature ${ }^{1,2}$. RAD is a common disorder among women during the third trimester of pregnancy with a high prevalence (66\% to $100 \%)$, approximately $50 \%$ of individuals who underwent abdominal hysterectomies or hernia repair were diagnosed with RAD as well ${ }^{3-7}$. It is increasingly recognized as it may be associated with symptomatic umbilical and/or epigastric hernia, aneurysmal disease, low back pain and muscular imbalance ${ }^{8-18}$.

There is no current consensus on the treatment of RAD, nor is there unity on the repair techniques among the surgical and physical and rehabilitative communities ${ }^{19-21}$, although a large body of literature has been generated on the restoration of some degree of strength of the midline in the postpartum setting, and many different innovative methods for surgical treatment to repair the defeat are available: vertical incision from the xiphoid process to the umbilicus or a low transverse skin incision, the repair of diastasis recti combined with liposuction, with or without using mesh to repair the rectus abdominis diastasis as well, etc. Based on the current literature, the promising results of new procedures with mesh placement and recurrent rate after long-term follow-up have not been clearly reported yet 22,23 .

Therefore, evaluating the effect of both physical therapy and repair surgery interventions is important, because RAD is wide-spread, significantly downgrading the quality-of-life (QoL) and increasing the costs of health care burden as well.

To better understand what is about the therapy and its outcomes of RAD, we conducted a retrospective study concerning the mesh placement and the systematic review summarizing operative-interventions and non-operative interventions in patients with RAD. Our result possibly may aid our understanding of RAD and help physiotherapists, surgeons and patients with RAD to make intervention strategy decision when encountering RAD patients.

\section{Methods}

This study followed a two-step procedure: (1) a retrospective analysis summarizing the outcomes of repairing of abdominal wall and hernia with mesh based on the data extracted from the Research Patient Data Registry (RPDR) in Massachusetts, USA; (2) a systematic literature review of intervention studies evaluating the effects of operative versus non-operative strategies on patients with RAD. The current review was registered on PROSPERO and can be accessed at www.crd.york.ac.uk/PROSPERO/display_record.asp? (CRD42018115608). We applied the PRISMA reporting guidelines for this review.

Page $2 / 23$ 


\section{Retrospective study}

\section{Materials and Methods}

This retrospective study analyzed the outcomes of patients with RAD who underwent mesh placement from six hospitals within the Partners Healthcare System in Massachusetts, United States. The review board of RPDR approved this study protocol (\#2018P003056). Patients with a diagnosis of RAD who underwent the mesh placement procedure were eligible. RAD was defined as an inter-rectus distance (IRD) of or more than $22 \mathrm{~mm}$, three centimeters above the umbilicus measured in a relaxed state ${ }^{24}$. Exclusion criteria were the implantation of mesh was not used for the repairing of abdominal wall and hernia. Identified individuallevel data of eligible patients from January 2011 to November 2018 was obtained from RPDR. Data including demographic information (age, body mass index (BMI), race or ethnic group), social history (smoking status, alcohol abuse, depressive disorder), diagnosis (including contaminant conditions possibly associated with RAD: hernia, low back pain, pelvic and perineal pain, incontinence, strain of muscle, fascial and tendon (SMFT), the history of open abdominal surgery, operative notes, imaging reports and procedures were collected. The diagnoses above were as defined by the International Classification of Diseases, Ninth Revision Clinical Modification ICD-9-CM and International Statistical Classification of Diseases and Related Health Problems, Tenth Revision ICD-10-CM diagnoses codes.

\section{The outcome indexes}

The primary outcome was the recurrence of RAD and hernia, and the second outcome was a composite of concomitant conditions (hernia, low back pain, pelvic and perineal pain, incontinence, strain of muscle, fascial and tendon (SMFT), depressive disorder and the peri-operative characteristics (operation type, anesthesia type, mesh type, skin closed method and adhesions in abdominal cavity noted on operate notes)

\section{Statistical analysis}

All statistical analyses were performed using IBM SPSS Statistics, version 20. Data were summarized as mean and standard deviation or frequencies and percentages where applicable. Chi-square test or Fisher's exact test were used to analyze categorical variables and Independent-Samples T test was used for continuous variables. binary logistic regression analysis to determine the association between the potential factors and the primary outcome, and the odds ratio and $95 \%$ confidence interval were estimated from BLRA. To reduce confounding bias, we adopted a forward stepwise regression analysis (a entry $=0.10, a$ removal $=0.10$ ). A $P$ value $<0.05$ was considered statistically significant.

\section{Results}

\section{Characteristics of the patients}

Of 82 patients who were reviewed at the 6 clinical settings from January 2011 through November 2018, 45 were female who received 54 mesh placement procedures totally and 37 were male who received 53 procedures. These patients were all diagnosed with RAD combined with one or more hernia. The mean age undergoing first time hernia repair in males was significantly older than that of females (mean 61.2 years old vs. 49.2 years old, $t=4.654, P=0.000$ ). The mean BMl values were greater than $30 \mathrm{~kg} / \mathrm{m}^{2}$ in both groups (mean 31.8 vs. $31.6, \chi^{2}=0.147, P=0.883$ ). The number of individuals smoking at index repair and using alcohol were high in both groups ( $37.8 \%$ vs. $31.1 \%, 54.1 \%$ vs. $48.9 \%$, respectively) (Table 1$)$.

\section{The outcomes}

The 5-year cumulative incidence of recurrence of and RAD and hernia was 37.0\% in female group compared with $43.4 \%$ in male group $\left(\chi^{2} 0.450, P=0.557\right.$, Figure 1$)$. While the recurrence after a one-year follow-up in male group was higher than in female group ( $24.53 \%$ vs. $5.56 \%, \chi^{2} 0.7 .571, P=0.007$, Figure 1$)$. We failed to identify risk factors contributing to recurrence after the repair with mesh when practicing binary logistic regression analysis by using 17 independent variables including age, race, concomitant conditions, mesh type, suture type, etc. As for the composite second outcomes, ventral hernia was most common type $(27.8 \%$ vs. 
$40.7 \%, P=0.104)$ and there was no difference in hernia number and type between two groups $(P=0.176)$. The rate of concomitant low back pain were higher than $30 \%$ as well in both groups (35.1\% vs. $33.3 \%, P=1.000)$, whereas depressive disorder and major depressive disorder in female group were significantly higher than that in male groups $(51.1 \%$ vs. $27.0 \%, P=0.041 ; 46.7 \%$ vs. $21.6 \%$, $P=0.022$, respectively). Over one-quarter cases had noted adhesion in abdominal cavity and there was no significant difference between two groups $(29.7 \%$ vs. $35.6 \%, P=0.641)$. Of 37 cases in male group, $20(62.5 \%)$ had the history of open abdominal surgery compared to 33 of 45 cases $(76.7 \%)$ in female group $(P=0.207)$ (Table 1$)$. The most common anesthesia type was general anesthesia and the suture was used to close skin commonly in both groups $(79.2 \%$ vs. $85.2 \%, 86.8 \%$ vs. $88.9 \%$, respectively). In female group, risk of coexisting with low back pain in patients with pelvic and perineal pain was 27 times greater than that of those without pelvic and perineal pain (OR 28.653; $95 \% \mathrm{Cl} 2.924,280.753 ; P=0.004)$; and patients with concomitant SMFT were more likely to have low back pain than those without SMFT as well (OR 9.604; 95\% Cl 0.763, 120.858; $P=0.08)$.

\section{Systematic review}

\section{Materials and Methods}

This study was conducted according to the Modified Downs and Black checklist for randomized and non-randomized studies of healthcare interventions (DB) ${ }^{25}$.

\section{Search strategy}

Systematic searches were conducted using Pubmed, Embase, and The Cochrane Library databases from the earliest data available to November 2018. The search terms used were "diastasis recti abdominis", "diastasis recti", "diastsis rectus abdominus", "abdominal rectus diastasis", "diastasis of the rectus abdominis muscle", "linea alba", " diastasis recti and weakness of the linea alba", and their combinations with Boolean "AND" and "OR" intervention terms, including "surgery", "surgical intervention", "reconstructive surgery", "surgical treatment", "prolotherapy", "regeneration injection therapy", "operative repair", "abdominal wall repair", "non-surgical intervention", "conservative treatment", physiotherapy", "physical therapy", "conservative management", "conservative therapy", "exercise”, "recommendation", "counsel”, "manual therapy", "strengthening", "movement”, "fitness program”, "external support", "band", "tape", "belt", "tubigrip", "drills". There were no restrictions placed on study design, but only full texts in English were included. We performed also manually searched the included references of relevant papers to ensure full coverage.

\section{Study selection}

Titles and abstracts were reviewed independently by three reviewers ( $\mathrm{Li}$ YX, Fan L and Li Q) to determine the eligibility of the papers for inclusion. The research team discussed and resolved issues together if there were any disagreements. Studies meeting all the following criteria were included:1) the study included at least one intervention that aimed to improve RAD; 2) the study was designed as a prospective, retrospective, clinical trial, or case report; 3) Full-text journal articles in English. Cadaver studies and animal studies were excluded.

\section{Data extraction and outcome measures}

Outcomes of the systematic review were overall presence/absence of RAD, RAD size/width, patient satisfaction, recurrence rate, physical activity levels, back pain, functional impairments, quality of life, follow-up information, and adverse events. Data on the type of study and sample size, the nationality of the enrolled patients, and the patients' age, sex, $\mathrm{BMI}\left(\mathrm{Kg} / \mathrm{m}^{2}\right)$, the types of anesthesia used during the surgical operation were also extracted. 
All included papers were evaluated for methodological quality using DB, which has a total maximum modified DB score of 28 and consists of four factors: external validity, confounders, bias, and power ${ }^{25}$. Articles with a DB score were grouped into the following quality levels: strong ( $\geq 21$ ), moderate (14-20), limited (7-13), or poor (7 or less) ${ }^{26}$. The final set of papers varied in outcome reporting; therefore, a meta-analysis was not possible.

\section{Results}

\section{Study identification}

The initial database search yielded 3906 articles, and two were obtained by tracking the references. After removing 739 duplicates, 3169 studies were screened for further analysis. Since 3102 did not match the review criteria, 67 full-text articles were screened for eligibility; of these, 40 were excluded later. Therefore, 37 studies were included in this systematic review. The flow diagram and reasons for study exclusion are shown in Fig. 2.

\section{Characteristics of the included studies}

The characteristics of all 2372 patients from the 37 included studies are presented in Tables 1 and 211,12,17,20,22,27-58. 1341 (69.02\%) patients in the surgery group and 422 (98.37\%) patients in the non-surgery group were female; the gender of 607 patients was not reported. BMI was reported in 20 studies (the average BMI was $>23 \mathrm{~kg} / \mathrm{m}^{2}$ in each reported study). There are four randomized controlled trials in the non-surgery group and three prospective clinical trials in the surgery group.

\section{Quality assessment}

Of the studies examining surgery intervention, 11 were of moderate quality, 13 were of limited quality, and three were of poor quality; of the studies examining non-surgery intervention, four were of strong quality, four were of moderate quality, and two were of limited quality. The average modified DB score of the included studies for the surgery intervention group was 11.7 (range 6-20), and that for the non-surgery group was 18.4 (range 12-26).

\section{Type of anesthesia}

Fifteen studies described the type of anesthesia, ten used general anesthesia, two used local anesthesia, and three used general anesthesia combined with epidural anesthesia. There were no complications due to anesthesia reported in any of the included studies.

\section{Operative intervention}

Eight studies (29.63\%) reported the use of endoscopy during abdominoplasty surgery; the remaining studies (70.37\%) were performed using a vertical skin incision from the xiphoid process to the umbilicus or a low transverse skin incision. The mesh augmentation technique was used to reinforce the linea alba with or without associated hernias in nine studies (33.33\%), and the type of mesh used included polypropylene, self-adhesive synthetic, composite, and resorbable vinyl mesh.

In eight studies (29.63\%), liposuction was combined with traditional abdominoplasty and repair of the rectus sheath defect to reduce complications and provide fast recovery; the volume of abdominal lipoaspirate ranged from 50 to $2800 \mathrm{ml}$, and the maximum volume reported in these studies was $7800 \mathrm{ml}$. Five studies $(18.52 \%)$ reduced recurrence by adopting a special suture 
method, such as the triangular mattress suture, continuous suture, the Venetian blinds application technique, braided suture, buried suture, and figure-of-eight suture combined with the wearing of self-adherent silicone strips.

\section{Non-operative intervention}

Muscle strength training, such as training of the pelvic floor muscles, abdominal muscles, rectus abdominis, internal/external oblique, or transverse abdominal muscles, was performed in all included non-surgery studies. Physical interventions including head lift, pelvic lock or tilt, plank, superman, and double leg raise were induced into the intervention program in two studies. The frequency was from one to 14 times per week, and the period of intervention was from 8 weeks to 15 months unequally.

\section{Outcomes}

The conclusions from six studies $(60 \%)$ in the non-surgery group were positive, and the remainder (40\%) were negative. The indexed outcomes included one or more of the following: inter recti distance (IRD), BMI, abdominal strength, pain, quality-of-life (QOL), pelvic floor distress index (PFDI), and activation endurance (hold seconds). In the surgery group, 26 studies (96.30\%) obtained positive results over the short-term, and just one study (3.70\%) reported negative results over the long-term. The indexed outcomes in this group included one or more of the following: the width of the diastasis of the recti abdominis muscles, ventral hernia pain, qualityof-life, Oswestry Disability Index, abdominal wall function, cosmetic outcome, satisfaction, Aponeurosis Shortening Index (ASI), back pain after surgery, and recurrence rate. None of the included studies demonstrated that physical training can be effective in improving the abdominal wall function of patients suffering RAD combined with hernia.

\section{Recurrence rates}

In the surgery group, there were seven studies $(25.93 \%)$ including a total of 603 subjects with a reported follow up of 12 months; no patient relapsed; after a follow up of 24 months, the three remaining studies $(11.11 \%)$ reported a $0 \%$ recurrence in a total of 268 subjects. Van reported a $40 \%$ recurrence rate of standard plication of the abdominal wall with absorbable material after a follow up of 5 years in a retrospective study of 40 patients attending a follow-up ultrasound investigation and with a total sample size of 70 women. No residual or recurrent diastasis was reported among 228 subjects receiving experimental training in the non-surgery group.

\section{Adverse events}

Twenty-four studies (85.19\%) including a total of 1989 patients described adverse events associated with the surgery, which included: seroma (102 cases, 5.13\%), sensibility disorder of the abdominal skin (45 cases, 2.26\%), minor scar (31 cases, $1.56 \%$ ), necrosis (umbilical/skin/sterile/infected fat) (19 cases, $0.96 \%$ ), pain (13 cases, $0.65 \%)$, wound infection (13 cases, $0.65 \%)$, dog-ears (9 cases, $0.45 \%)$, hematoma ( 8 cases, $0.40 \%$ ), sensibility disorder of the thigh (6 cases, $0.30 \%$ ), epigastric fullness ( 4 cases, $0.20 \%)$, full-thickness skin loss ( 3 cases, $0.15 \%$ ), prolonged neuralgia ( 3 cases, $0.15 \%$ ), thrombosis (3cases, $0.15 \%)$, discrete wound (3 cases, $0.15 \%)$, subcutaneous emphysema ( 2 cases, $0.10 \%)$, transient scalp alopecia ( 1 case, $0.05 \%)$, pulmonary embolism ( $1 \mathrm{case,}$ $0.05 \%$ ), pneumonia ( 1 case, $0.05 \%$ ), subdermal burn ( 1 case, $0.05 \%$ ), epidermolysis ( 1 case, $0.05 \%$ ), and postoperative ileus ( 1 case, $0.05 \%)$. There were no adverse events reported in patients with physical training.

\section{Discussion}

\section{Summary of results}

This systematic review found a limited strength of evidence that abdominoplasty and diastasis recti repair with or without mesh and/or liposuction may be effective at restoring the function of the rectus muscles, improving the stability of the abdominal wall 
and upgrading the quality of life in the short-term. However, the post-operative recurrence rate in patients who underwent either traditional standard vertical plication or modern endoscopic surgery increased rapidly with the time, a rate of up to 40 percent was reported in one study, and this high recurrence rate also has been confirmed in our retrospective study.

Our study also found a moderate strength of evidence that physical training including strength training of the pelvic floor muscles, transverse abdominal muscle, core stabilization, and rehabilitation therapy have limited effectiveness for the rehabilitation of diastasis rectus muscles, especially for patients suffering from RAD combined with hernia.

Among all twenty-one types of complications reported in the included studies, the rate of seroma was the highest at five percent, which was higher than other reported ${ }^{59}$. A large body of evidence shows that the use of drains in abdominoplasty may increase the seroma rate, while surgeons are unwilling to change their clinical practice of using drains ${ }^{60}$. Meanwhile, thrombosis and pulmonary embolism were reported in these studies, but their final outcomes and the reason leading to the severe adverse events were not reported. Therefore, an understanding of how to prevent these adverse events due to diastasis rectus abdominus repair surgery is also needed and will require further, in-depth research.

Therefore, the problems of how to reduce the recurrence rate and adverse events related to procedure remains although surgeons have tried innovative suture techniques or materials, such as triangular mattress suture, smooth running absorbable polydioxanone suture, nylon, or polydioxanone and/or different meshes, or in combination with liposuction abdominoplasty, etc. In this retrospective study, we found that, obesity was an important characteristic in both male and female patients with RAD. In addition, the rate of noted adhesion in abdominal cavity was high, similar to previous study ${ }^{61}$. These adhesions played an important role in increasing the difficulty of operation performing due to extensive adhesions. Whether the adhesion in abdominal cavity was related to the recurrence of RAD and hernia was unknown. In the field of fascia research, researchers found that a previously unknown feature of human anatomy, termed a newfound "organ", exists in numerous tissues, including the submucosae of the entire gastrointestinal tract and urinary bladder, the dermis, the peribrochial and peri-arterial soft tissues, and the fascia; this may play an important role in the mechanical functioning of many or all tissues and organs, cancer metastasis, edema, and fibrosis ${ }^{62}$. Other researchers found that telocytes exist in human fascia, which may contribute to some common diseases such as stiffening of limbs, inflammatory diseases, sclerotic and the progression of fibrotic, etc ${ }^{63}$, but the exact role of these cells is unknown ${ }^{64}$. It was also reported that fascia lesions were closely related with chronic pain ${ }^{65}$. We confirmed that women with SMFT were also more likely to coexisting with LBP than those without SMFT, which is consistent with myofascial pain theory as well ${ }^{26}$. We demonstrated that RAD is most common among obesity population and more than 33 percent of them were coexisting with low back pain. In addition, women with SMFT had more than 9 times of risk of coexisting with low back pain than those without SMFT; we also found that the volume of intra-abdominal and superficial fat being removed during abdominoplasty surgery is closely associated with the outcome. Is there a close relationship between the fat removed by surgeons and the newfound "organ" with telocytes? The authors want to boldly make a hypothesis here, and further study is warranted to examine this most possibly association.

In conclusion, this systematic review found a moderate strength of evidence that physical training has limited effectiveness for the rehabilitation of diastasis rectus muscles, especially for those patients suffering from RAD combined with hernia, and abdominoplasty and diastasis recti repair with or without mesh and/or liposuction may be effective at restoring the functions of the rectus muscles and improving the stability of the abdominal wall and quality of life in the short-term; however, up to now, the longterm durability and the adverse events are unsatisfactorily, these all need further, in-depth research.

\section{Limitations}

Several limitations existed in this study. Firstly, the methodological quality, especially in the surgery group, was weak. Secondly, a meta-analysis of the studies was not performed given the lack of consistency in the interventions. Thirdly, the results of the review may be influenced by publication bias because we did not contact the authors about other possibly existing unpublished analyses, nor did we search for unpublished studies. 


\section{Recommendations for future research}

RAD is common and may be associated with low back pain and impaired health-related quality of life. Fortunately, mounting evidence indicates that surgery repair and physical training have helped many patients in improving their quality of life. However, why is RAD very common among people with high $\mathrm{BMI}$, why does the diffuse fusiform bulge reappear to a large extent even when mesh is used, and why is the outcome possibly better when abdominoplasty combined with liposuction is used rather than the standard method? Whether or not there is a closely relationship between surface and deep fascia lesions? Many puzzles remain to be explored. Therefore, future research should pay more attention to the pathogenesis of RAD based on a multidisciplinary cooperative team of experts, including at least the departments of plastic surgery, radiology, ultrasound imaging, and pathology as well as the fascia research center.

\section{Conclusion}

This review found a limited strength of evidence that abdominoplasty and diastasis recti repair with or without mesh and/or liposuction may be effective at restoring the functions of the rectus muscles and improving the stability of the abdominal wall and quality of life in the short-term; a moderate strength of evidence was found that strength training has a limited effect, especially for those patients suffering RAD combined with hernia. To maximize long-term efficacy, a multidisciplinary cooperative team including experts from at least the departments of plastic surgery, radiology, ultrasound imaging, and pathology as well as the fascia research center is urgently needed because abdominoplasty represents the fourth most-common aesthetic surgery procedure according to the reports published by American Society for Aesthetic Plastic Surgery in $2014{ }^{66}$.

\section{Abbreviations}

RAD: rectus abdominis diastasis; DB: Downs and Black checklist; QoL:quality-of-life; RPDR: IRD: inter-rectus distance; BMI: body mass index; SMFT: strain of muscle, fascial and tendon; ICD: International Classification of Diseases; OR: odds ratio; Cl: confidence interval; BLRA: binary logistic regression analysis; ASI: Aponeurosis Shortening Index.

\section{Declarations}

\section{Ethics approval and consent to participate}

The review board of the Research Patient Data Registry (RPDR) approved this retrospective study protocol (\#2018P003056). As for the systematic review, the ethics approval is not required.

\section{Consent for publication}

Not applicable.

\section{Availability of data and materials}

As a review study, the data were extracted from the Research Patient Data Registry (RPDR) in Massachusetts, USA; as for the systematic review, the data were extracted from Pubmed and The Cochrane Library databases. The data supporting our findings can be obtained by emailing the corresponding author.

\section{Competing interests}

The authors declare that they have no competing interests.

\section{Funding}

Not applicable.

\section{Authors' contributions}


Sue Yuan: This author helped develop ideas for study, design the study, collect data, analyze data, and prepare the manuscript for publication. Yunxia Li, Qi Li, Lu Fan: This author helped developed ideas for study and review the manuscript. Jie Zhou: This author contributed to the developing of ideas, the study design, manuscript preparation for publication.

\section{Acknowledgements}

Not applicable.

\section{References}

1. Nahabedian M, Brooks D. Rectus abdominis diastasis. UpToDate. https://www.uptodate.com/contents/rectus-abdominisdiastasis\#!(Accessed May 19,2019).

2. Mommers E, Ponten J, Omar AK, Reilingh TS, Bouvy ND, Nienhuijs SW. The general surgeon's perspective of rectus diastasis. A systematic review of treatment options. Surg Endosc 2017; 31:4934-4949.

3. Earle DB, McLellan JA. Repair of umbilical and epigastric hernias. Surg Clin North A 2013; 93:1057

4. Venclauskas L, Silanskaite J, Kiudelis M. Umbilical hernia: factors indicative of recurrence. Medicina(Kaunas) 2008; $44: 855$

5. Skandalakis PN, Zoras O, Skandalakis JE, Mirilas P. Spigelian hernia: surgical anatomy, embryology, and technique of repair. Am Surg 2006; 72:42

6. Boissonnault JS, Blaschak MJ. Incidence of diastasis recti abdominis during the childbearing year. Phys Ther 1998; 68:1082-6

7. Hanneford R, Tozer J. An investigation of the incidence, degree and possible predisposing factors of the rectus diastasis in the immediate post-partum period. J Nat Obstet Gynaecol Special Group Aust Physiother Assoc 1985; 4:29-32

8. Bursch SG. Interrater reliability of diastasis recti abdominis measurement. Phys Ther 1987; 67:1077-9.

9. Lee DG, Lee LJ, McLaughlin L. Stability, continence and breathing: the role of fascia following pregnancy and delivery. J Bodywork Move Ther 2008; 12:333-48.

10. Gilleard, W.L., Brown, J.M. Structure and function of the abdominal muscles in primigravid subjects during pregnancy and the immediate postbirth period. Physical Therapy. American Physical Therapy Association 1996; 76 (7): 750-762.

11. Kockerling F, Botsinis MD, Rohde C, Reinpold W. Endoscopic-associated linea alba reconstruction plus mesh augmentation for treatment of umbilical and/or epigastric hernias and rectus abdominis diastasis-early results.Frontiers in surgery 2016 May; 3:1-6.

12. Emanuelsson P, Gunnarsson U, Dahlstrand U, Strigard K, Stark B. Opearative correction of abdonimal redtus diastasis (ARD) reduces pain and improves abdominal wall muscle strength: a randomized, prospective trial comparing retromuscular mesh repair to ouble-row, self-retaining sutures. Surgery Nov 2016;1367-1375.

13. McPhail I. Abdominal aortic aneurysm and diastasis recti. Angiology 2008; 59:736.

14. Rath AM, Attali P, Dumas JL, Goldlust D, Zhang J, Chevrel JP. The abdominal linea alba: an anatomo-radiologic and biomechanical study.Surg Radiol Anat 1996; 18:281-8.

15. Hibbs AE, Thompson KG, French D, Wrigley A, Spears I. Optimizing performance by improving core stability and core strength. Sports Med 2008; 38(12): 995-1008.

16. Heiderscheit BC, Sherry MA, Silder A, Chumanov ES, Thelen DG. Hamstring strain injuries: recommendations for diagnosis, rehabilitation, and injury prevention. J Orthop Sports Phys Ther 2010; 40 (2):67-81.

17. Bellido Luque J, Bellido Luque A, Valdivia J, Suarez Grau J.M, Gomez Menchero J, Garcia Moreno J, Guadalajara Jurado J. Totally endoscopic surgery on diastasis recti associated with midline hernias. The advantages of a minimally invasive approach. Prospective cohort study. Jun 2015;19(3):493-501.

18. Zhou J, Yuan S. Delivery Mode is Associated with Rectus Abdominis Diastasis: A Retrospective Cohort Study. Society for Obstetric Anesthesia and Perinatology. May 3, 2019, Phoenix, Arizona.

19. Benjamin DR, Water ATM, Peiris CL. Effects of exercise on diastasis of the rectus abdominis muscle in the antenatal and postnatal periods: a systematic review. Physiotherapy 2014; 100:1-8.

20. Gluppe SL, Hilde M, Tennfjord MK, Engh ME, Bø K. Effect of a Postpartum Training Program on the Prevalence of Diastasis Recti Abdominis in Postpartum Primiparous Women: A Randomized Controlled Trial there are few data to guide its 
management. Physical therapy 2018; 98(4):260-268.

21. Mesquita LA, Machado AV, Andrade AV. Physiotherapy for Reduction of Diastasis of the Recti Abdominis Muscles in the Postpartum Period. Rev Bras Ginecol Obstet 1999; 21:267

22. Tadiparthi S, Shokrollahi K, Doyle GS, Fahmy FS. Rectus sheath plication in abdominoplasty: assessment of its longevity and a review of the literature. J Plast Reconstr Aesthet Surg 2012; 65:328-332.

23. Hickey F, Finch JG, Khanna A. A systematic review on the outcomes of correction of diastasis of the recti. Hernia 2011; 15:607.

24. Beer GM, Schuster A, Seifert B, Manestar M, Mihic-Probst D, Weber SA. The normal width of the linea alba in nulliparous women. Clin Anat 2009; 22(6):706-711.

25. Downs SH, Black N. The feasibility of creating a checklist for the assessment of the methodological quality both of randomised and non-randomised studies of heathcare interventsions. J Epidemiol Community Health 1998; 52:377-384

26. Malanga GA, Cruz Colon EJ. Myofascial Low Back Pain: A Review. Phys Med Rehabil Clin N Am 2010; 21(4):711-724.

27. Muas DMJ. Preaponeurotic endoscopic repair (REPA) of diastasis recti associated or not to Midline hernias. Surgical Endoscopy September 2018;18:1-6.

28. Köckerling F, Botsinis MD, Rohde C, Reinpold W, Schug-Pass C. Endoscopic-assisted linea alba reconstruction. Eur Surg March 2017; 49:71-75.

29. Gallus KM, Golberg KF, Field R. Functional Improvement Following Diastasis Rectus Abdominus Repair in an Active Duty Navy Female. MILITARY MEDICINE August 2016; 181:e952-954.

30. Privett B. J; Ghusn M. Proposed technique for open repair of a small umbilical hernia and rectus divarication with self-gripping mesh. Hernia 2016; 20:527-530.

31. Shirah BH, Shirah HA. The Effectiveness of Polypropylene Mesh in the Open and Laparoscopic Repair of Divarication of the Recti. Journal of Medical Implants and Surgery 2016; 1(1):1-4.

32. Veríssimo P, Nahas FX, Jardini Barbosa MV, Carvalho Gomes HF, Ferreira LM. Is it Possible to Repair Diastasis Recti and Shorten the Aponeurosis at the Same Time? Aesth Plast Surg 2014; 38:379-386.

33. Kanjoor J. R., Singh A. K. Lipoabdominoplasty: An exponential advantage for a consistently safe and aesthetic outcome. Indian Journal of Plastic Surgery 2012; 45(1):77-89.

34. Rosen A, Hartman T. Repair of the Midline Fascial Defect in Abdominoplasty With Long-Acting Barbed and Smooth Absorbable Sutures. Aesthetic Surgery Journal 2011;31(6): 668-673.

35. Pechter EA. Instant Identification of Redundant Tissue in Abdominoplasty with a Marking Grid. Aesthetic Surgery Journal 2010; 30(4): 571-578.

36. Siddiky A.H, Kapadia C.R. Laparoscopic plication of the linea alba as a repair for diastasis recti - a mesh free approach. Journal of Surgical Case Reports 2010; 5:3.

37. Brauman D, Capocci J. Liposuction Abdominoplasty: An Advanced Body Contouring Technique. the American Society of Plastic Surgeons November 2009; 1685-1695.

38. Palanivelu C, Rangarajan M, Jategaonkar P.A, Amar V, Gokul K. S, Srikanth B. Laparoscopic repair of diastasis recti using the 'Venetian blinds' technique of plication with prosthetic reinforcement: a retrospective study. Hernia 2009; 13:287-292.

39. Batchvarova Z, Leymarie N, Lepage C, Leyder P. Use of a Submuscular Resorbable Mesh for Correction of Severe Postpregnancy Musculoaponeurotic Laxity: An 11-Year Retrospective Study. the American Society of Plastic Surgeons 2008; 121(4):1240-1248.

40. Dabb RW, Hall WW, Baroody M, Saba AA. Circumferential Suction Lipectomy of the Trunk with Anterior Rectus Fascia Plication through a Periumbilical Incision: An Alternative to Conventional Abdominoplasty. PLASTIC AND RECONSTRUCTIVE SURGERY February 2004; 727-732.

41. Nahas FX, Ferreira LM, Arimate'ia Mendes J. An Efficient Way to Correct Recurrent Rectus Diastasis. Aesth. Plast. Surg 2004; 28:189-196.

42. Restrepo JCC, Ahmed JAM. New technique of plication for miniabdominoplasy. Plication for minabdominoplasty 2010; 109(3): 1170-1177. 
43. Ferreira LM, Castilho HT, Castilho J, Ardenghy M, Toledo SR, Cruz RG, Tardelli H. Triangular Mattress Suture in Abdominal Diastasis to Prevent Epigastric Bulging. Annals of Plastic Surgery 2001; 46(2):130-134.

44. Nahas FX, Augusto SM, Ghelfond C. Nylon versus polydioxanone in the correction of rectus diastasis. Plastic and reconstructive surgery 2001; 107(3):700-706.

45. Nahas FX. An aesthetic classification of the abdomen based on the myoaponeurotic layer. Plastic and reconstructive surgery 2001; 108(6):1787-1795.

46. Uchelen J.H., Kon M, Werker P M.N. The long-term durability of plication of the anterior rectus sheath assessed by ultraonography. Plastic and reconstructive surgery 2001; 107(6):1578-1584.

47. Ramirez OM. Abdominoplasty and abdominal wall rehabilitation: a comprehensive approach. Plastic and reconstructive surgery 1999; 105(1):425-435.

48. Zukowski M L, Ash K, Spencer D, Malanoski M, Moore G. Endoscopic intracorporal abdominoplastry: a review of 85 cases. Plastic and reconstructive surgery 1998; 102(2):516-527.

49. Asaadi M, Haramis HT. A simle technique for repair of rectus sheath defects. Annals of plastic surgery 1994; 32(1):107-109.

50. Kamel DM, Yousif M. Neuromuscular electrical stimulation and strength recovery of postnatal diastasis recti abdominis muscles. Ann Rehabil Med 2017; 41(3):465-474.

51. Khandale SR, Hande D. Effects of abdominal exercises on reduction of diastasis recti in postnatal women. International journal of health sciences and research 2016; 6(6):182-191.

52. Walton LM, Costa A, LaVanture D, Mcllrath S, Stebbins B. The effects of a 6-week dynamic core stability plank exercise program compared to a traditional supine core stability strengthening program on diastasis recti abdominis closure, pain, oswestry disability index (ODI) and pelvic floor disability index scores (PFDI). Physical therapy and rehabilitation 2016; 3:1-9.

53. Acharry N, Kutty RK. ABDOMINAL EXERCISE WITH BRACING, ATHERAPEUTIC EFFICACY IN REDUCING DIASTASIS-RECTI AMONG POSTPARTAL FEMALES. International journal of health sciences and research 2015; 3(2):999-1005.

54. Balius R, Pedret C, Pacheco L, Gutierrez JA, Vives J, Escoda J. Rectus abdominis muscle injuries in elite handball players: management and rehabilitation. Journal of Sports Medicine 2011; 2:69-73.

55. Chiarello CM, Falzone LA, McCaslin K, Patel M, Ulery KR. The Effects of an Exercise Program on Diastasis Recti Abdominis in Pregnant Women. Journal of Women's Health Physical Therapy Spring 2005; 29(1):11-16.

56. Hsia M, Jones S. Natural resolution of rectus abdominis diastasis. Two single case studies. Australian Journal of Physiotherapy 2000; 46: 301-307.

57. Sheppard. The role of transversus abdominus in postpartum correction of gross divarication recti. Manual therapy 1996; 1(4):214-216.

58. Brauman D. liposuction abdominoplasty: an evolving concept. Plastic and Reconstructive Surgery 2003; 112(1):288-298.

59. Pollock TA, Pollock H. Progressive tension sutures in abdominoplasty: a review of 597 consecutive cases. Aesthet Surg J 2012; 32(6):729-742.

60. Macias LH, Kwon E, Gould DJ, Spring MA, Stevens GS. Decrease in seroma rate after adopting progressive tension sutures without drains: s single surgery center experience of 451 abdominoplasties over 7 years. Aesthetic surgery journal 2016; 36(9):1029-1035.

61. Kozman MA, Tonkin D, Eteuati J, Karatassas A, McDonald C. Robotic-assisted ventral hernia repair with surgical mesh: how I do it and case series of early experience. Royal Australasian College of Surgeons. 2019 Mar;89(3):248-254.

62. Benias PC, Wells RG, Sackey-Aboagye B, Klavn H, Reidy J, Buonocore D, Miranda M, Kornacki S, Wayne M, Carr-Locke DL, Theise ND. Structure and distribution of an unrecognized interstitium in human tissues. Scientific reports 2018; 8:4947.

63. Dawidowicz J, Szotek S, Matysiak N, Mielańczyk $Ł$, Maksymowicz K.Electron microscopy of human fascia lata: focus on telocytes. J Cell Mol Med. 2015 Oct;19(10):2500-6.

64. Dawidowicz J, Szotek S, Matysiak N, Mielanczyk L, Maksymowicz K. Electron microscopy of human fascia late: focus on telocytes. Journal of cellular and molecular medicine 2015; 19(10):2500-2506.

65. Creze M, Soubeyrand M, Timoh KN, Gagey O. Organization of the fascia and aponeurosis in the lumbar paraspinal compartment. Surgical and Radiologic Anatomy 2018; 40:1231-1242.

Page $11 / 23$ 


\section{Tables}

\begin{tabular}{|c|c|c|c|c|}
\hline & Male group & Female group & $x^{2}$ & $P$ \\
\hline & $(n=37)$ & $(n=45)$ & & \\
\hline \multicolumn{5}{|l|}{ Demographic characteristics } \\
\hline Age (yr) (underwent first hernia repair) & & & & \multirow{3}{*}{$0.000^{a}$} \\
\hline Mean (sd) (year) & $61.2 \pm 12.3$ & $49.2 \pm 11.0$ & 4.654 & \\
\hline \multicolumn{4}{|l|}{ Category, n (\%) } & \\
\hline$<30$ & $1(2.7)$ & $0(0.0)$ & 19.139 & \multirow[t]{6}{*}{0} \\
\hline 30 to $<40$ & $1(2.7)$ & $8(17.8)$ & & \\
\hline 40 to $<50$ & $5(13.5)$ & $21(46.7)$ & & \\
\hline 50 to $<60$ & $6(16.2)$ & $5(11.1)$ & & \\
\hline 60 to $<70$ & $12(32.4)$ & $8(17.8)$ & & \\
\hline 70 to $<80$ & $12(32.4)$ & $3(6.7)$ & & \\
\hline \multicolumn{5}{|l|}{ Race or ethnic group, n (\%) } \\
\hline Non-Hispanic black & $0(0.0)$ & $3(6.7)$ & 2.141 & \multirow[t]{3}{*}{0.143} \\
\hline Hispanic & $2(5.4)$ & $4(8.9)$ & & \\
\hline Other & $35(94.6)$ & $38(84.4)$ & & \\
\hline \multicolumn{5}{|l|}{ Body mass index } \\
\hline Mean $\left(\mathrm{kg} / \mathrm{m}^{2}\right)$ & $31.8 \pm 5.4$ & $31.6 \pm 7.9$ & 0.147 & \multirow[t]{2}{*}{$0.883^{a}$} \\
\hline \multicolumn{4}{|l|}{ Category, n (\%) } & \\
\hline$<18.5$ & $0(0.0)$ & $1(2.2)$ & 2.974 & \multirow[t]{5}{*}{0.412} \\
\hline 18.5 to $<25$ & $5(13.5)$ & $5(11.1)$ & & \\
\hline 25 to $<30$ & $8(21.6)$ & $15(33.3)$ & & \\
\hline 30 to $<40$ & $22(59.5)$ & $19(42.2)$ & & \\
\hline$\geq 40$ & $2(5.4)$ & $5(11.1)$ & & \\
\hline \multicolumn{5}{|l|}{ Coexisting symptoms, n (\%) } \\
\hline \multicolumn{5}{|l|}{ Hernia, $\mathrm{n}(\%)$} \\
\hline Diaphragmatic hernia & $5(6.9)$ & $5(6.2)$ & 6.323 & \multirow[t]{5}{*}{0.176} \\
\hline Ventral hernia & $20(27.8)$ & $33(40.7)$ & & \\
\hline Groin hernia & $11(15.3)$ & $5(6.2)$ & & \\
\hline Incisional hernia & $16(22.2)$ & $22(27.2)$ & & \\
\hline Umbilical hernia & $20(27.8)$ & $16(19.8)$ & & \\
\hline Low back pain, n (\%) & $13(35.1)$ & $15(33.3)$ & 0.029 & 1 \\
\hline Pelvic and perineal pain, $\mathrm{n}(\%)$ & $4(10.8)$ & $8(17.8)$ & 0.789 & 0.374 \\
\hline Incontinence, $\mathrm{n}(\%)$ & $1(2.7)$ & $1(2.2)$ & 0.02 & $1.000^{\mathrm{b}}$ \\
\hline Strain of muscle, fascial and tendon, n (\%) & $2(5.4)$ & $4(8.9)$ & 0.363 & $0.685^{\mathrm{b}}$ \\
\hline Previous abdominal surgery history, n (\%) & $20(62.5)$ & $33(76.7)$ & 1.796 & 0.207 \\
\hline \multicolumn{5}{|l|}{ Social history, n (\%) } \\
\hline Smoker at index repair, $\mathrm{n}(\%)$ & $14(37.8)$ & $14(31.1)$ & 0.409 & \multirow{4}{*}{$\begin{array}{l}0.641 \\
0.664 \\
0.041 \\
0.022\end{array}$} \\
\hline Alcohol use, n (\%) & $20(54.1)$ & $22(48.9)$ & 0.217 & \\
\hline Depressive disorder, n (\%) & $10(27.0)$ & $23(51.1)$ & 4.898 & \\
\hline Major depressive disorder, n (\%) & $8(21.6)$ & $21(46.7)$ & 5.572 & \\
\hline \multicolumn{5}{|l|}{ Peri-operative characteristics, n (\%) } \\
\hline \multicolumn{5}{|l|}{ Operation type, n (\%) } \\
\hline Open abdominal & $35(66.0)$ & $44(81.5)$ & 3.302 & 0.081 \\
\hline Laparoscopic & $18(34.0)$ & $10(18.5)$ & & \\
\hline Anesthesia type, n (\%) & & & & \\
\hline General & $42(79.2)$ & $46(85.2)$ & 0.646 & 0.458 \\
\hline Monitored anesthesia care with local & $11(20.8)$ & $8(13.0)$ & & \\
\hline Spinal & $0(0.0)$ & $1(1.98)$ & & \\
\hline Mesh type, n (\%) & & & & \\
\hline Polypropylene & $29(54.8)$ & $18(33.3)$ & 7.177 & 0.028 \\
\hline Parietex & $12(22.6)$ & $11(20.4)$ & & \\
\hline John and Johnson prolene hernia system & $12(22.6)$ & $25(46.3)$ & & \\
\hline Skin closed method, n (\%) & & & & \\
\hline Suture & $46(86.8)$ & $48(88.9)$ & 0.11 & 0.74 \\
\hline Staples & $7(13.2)$ & $6(11.1)$ & & \\
\hline Adhesions in abdominal cavity, $\mathrm{n}(\%)$ & $11(29.7)$ & $16(35.6)$ & 0.312 & 0.641 \\
\hline
\end{tabular}

Table 2 Characteristics of included studies with operative intervention. 


\begin{tabular}{|c|c|c|c|c|c|c|c|c|}
\hline Study & Country & Design & $\begin{array}{l}\text { Sample } \\
\text { size } \\
\text { (Male, } \\
\text { Female) }\end{array}$ & Age (year) & $\operatorname{BMI}\left(\mathrm{Kg} / \mathrm{m}^{2}\right)$ & Anesthesia & Outcome Index/Tools & $\begin{array}{l}\text { Study } \\
\text { quality }\end{array}$ \\
\hline $\begin{array}{l}\text { Juárez Muas } \\
\text { DM }\end{array}$ & Argentina & Case study & $50(3 / 47)$ & $38(24-66)$ & $36 \%>28$ & $\begin{array}{l}\text { General } \\
\text { anesthesia }\end{array}$ & Recurrence of DRAM & $13 / 28$ \\
\hline \multicolumn{9}{|l|}{ 2018[1] } \\
\hline Kockerling $\mathrm{F}$ & Germany & $\begin{array}{l}\text { Prospective cohort } \\
\text { study }\end{array}$ & $\begin{array}{l}140 \\
(90 / 50)\end{array}$ & $\begin{array}{l}54.7(25- \\
85)\end{array}$ & $\begin{array}{l}29.9(18- \\
50)\end{array}$ & NR & DRAM presence, Recurrence of & $13 / 28$ \\
\hline $2017[2]$ & & & & & & & DRAM & \\
\hline $\begin{array}{l}\text { Emanuelsson } \\
\text { P 2016[3] }\end{array}$ & Sweden & $\begin{array}{l}\text { Prospective } \\
\text { randomized clinical } \\
\text { 2-armed trial }\end{array}$ & $\begin{array}{l}89(2 / 87) \\
\text { Intervention } \\
\text { group: } 54 \\
\text { Control } \\
\text { group: } 32\end{array}$ & $\begin{array}{l}\text { Quil group: } \\
39.6 \\
\text { Mesh } \\
\text { group: } 42 \\
\text { Control } \\
\text { group: } \\
\qquad 44.2\end{array}$ & $\begin{array}{l}\text { Quil } \\
\text { group:23.0 } \\
\text { Mesh } \\
\text { group:23.0 } \\
\text { Control } \\
\text { group: } \\
22.8\end{array}$ & $\begin{array}{l}\text { General } \\
\text { anesthesia }\end{array}$ & $\begin{array}{l}\text { Recurrence of ARD, width }(>3 \mathrm{~cm}) \text {, } \\
\text { the ventral hernia pain } \\
\text { Questionnaire, quality-of-life (SF- } \\
\text { 36), Abdominal muscle } \\
\text { strength }\end{array}$ & $20 / 28$ \\
\hline $\begin{array}{l}\text { Gallus KM } \\
2016[4]\end{array}$ & SanDiego & Case report & $1(0 / 1)$ & 24 & NR & Local anesthesia & Oswestry Disability Index & $10 / 28$ \\
\hline $\begin{array}{l}\text { Kockerling F } \\
2016[5]\end{array}$ & Germany & Case series & $40(29 / 11)$ & 53.6 & $\begin{array}{l}32.6(23- \\
50)\end{array}$ & NR & Postoperation complications & $14 / 28$ \\
\hline $\begin{array}{l}\text { Privett BJ } \\
2016[6]\end{array}$ & Australia & Case series & $\begin{array}{l}173 \\
(\mathrm{NR} / \mathrm{NR})\end{array}$ & NR & NR & NR & $\begin{array}{l}\text { Recurrence rate, } \\
\text { Postoperation complications }\end{array}$ & $6 / 28$ \\
\hline $\begin{array}{l}\text { Shirah BH } \\
\text { 2016[7] }\end{array}$ & Saudi Arabia & $\begin{array}{l}\text { Retrospective cohort } \\
\text { study }\end{array}$ & $\begin{array}{l}216 \\
(31 / 185)\end{array}$ & $40.9 \pm 2.7$ & $26.39 \pm 2.8$ & $\begin{array}{l}\text { General } \\
\text { anesthesia }\end{array}$ & $\begin{array}{l}\text { Recurrence rate, } \\
\text { Postoperation complications, } \\
\text { Abdominal wall function, } \\
\text { Cosmetic outcome }\end{array}$ & $15 / 28$ \\
\hline $\begin{array}{l}\text { Bellido LJ } \\
\text { 2015[8] }\end{array}$ & Spain & $\begin{array}{l}\text { Prospective cohort } \\
\text { study }\end{array}$ & $21(3 / 18)$ & $37.6 \square 24-50 \square$ & $\begin{array}{l}27.4(22- \\
35)\end{array}$ & $\begin{array}{l}\text { General } \\
\text { anesthesia }\end{array}$ & $\begin{array}{l}\text { surgical time(min), postoperative } \\
\text { stay (days), time of remove drain, } \\
\text { postoperative complications, } \\
\text { Recurrence, satisfaction, back pain } \\
\text { after surgery, Average distance } \\
\text { between the rectus }\end{array}$ & $16 / 28$ \\
\hline $\begin{array}{l}\text { Verissimo } P \\
2014[9]\end{array}$ & Brazil & $\begin{array}{l}\text { Prospective clinical } \\
\text { trial }\end{array}$ & $\begin{array}{l}31(0 / 31) \\
\text { TS:21 } \\
\text { CS:10 }\end{array}$ & $\begin{array}{l}\text { TS:33.6 } \\
\text { CS:37.4 }\end{array}$ & $\begin{array}{l}\text { TS :23.2 } \\
\text { CS : } 24.1\end{array}$ & $\begin{array}{l}\text { General } \\
\text { anesthesia } \\
\text { combined with } \\
\text { epidural }\end{array}$ & $\begin{array}{l}\text { Aponeurosis Shortening Index } \\
\text { (ASI) }\end{array}$ & $14 / 28$ \\
\hline $\begin{array}{l}\text { Kanjoor JR } \\
\text { 2012[10] }\end{array}$ & Canada & Retrospective study & $\begin{array}{l}146 \\
(8 / 138)\end{array}$ & $43(29-72)$ & $\begin{array}{l}<30=102 \\
>30=44\end{array}$ & $\begin{array}{l}\text { General } \\
\text { anesthesia } \\
\text { or Epidural } \\
\text { anesthesia } \\
\text { Combined with } \\
\text { sedation }\end{array}$ & Postoperation complications & $9 / 28$ \\
\hline $\begin{array}{l}\text { Tadiparthi S } \\
\text { 2012[11] }\end{array}$ & UK & $\begin{array}{l}\text { prospective } \\
\text { study }\end{array}$ & $28(0 / 28)$ & $36(23-47)$ & $26(21-37)$ & NR & Beer classification & $13 / 28$ \\
\hline Rosen A & USA & retrospective & $34(0 / 34)$ & $\begin{array}{l}43.6(33- \\
67)\end{array}$ & $\begin{array}{l}23(18.7- \\
29.1)\end{array}$ & $\begin{array}{l}\text { General } \\
\text { anesthesia }\end{array}$ & Recurrence rate, & $14 / 28$ \\
\hline $2011[12]$ & New Jersey & review & & & & & Postoperation complications & \\
\hline Pechter EA & USA & retrospective & $35(0 / 35)$ & $\begin{array}{l}40.7(23- \\
63)\end{array}$ & $\begin{array}{l}25.3(18.3- \\
37.2)\end{array}$ & $\begin{array}{l}\text { General } \\
\text { anesthesia }\end{array}$ & Ischemic complications & $14 / 28$ \\
\hline $2010[13]$ & & review & & & & & & \\
\hline Siddiky AH & USA & Case report & $1(0 / 1)$ & 38 & NR & NR & Recurrence rate, & $14 / 28$ \\
\hline $2010[14]$ & & & & & & & Post-operation Complications. & \\
\hline $\begin{array}{l}\text { Brauman D } \\
2009[15]\end{array}$ & USA & $\begin{array}{l}\text { Prospective } \\
\text { study }\end{array}$ & $\begin{array}{l}337 \\
(7 / 330)\end{array}$ & $36(21-72)$ & $\begin{array}{l}29.3(19.5- \\
41.7)\end{array}$ & Local anesthesia & Post-operation complications & $10 / 28$ \\
\hline Palanivelu C & India & Retrospective study & $18(5 / 13)$ & & $\begin{array}{l}28.6(25- \\
32.2)\end{array}$ & NR & IRD, Complications & $6 / 28$ \\
\hline
\end{tabular}

Page 13/23 


\begin{tabular}{|c|c|c|c|c|c|c|c|c|}
\hline \multicolumn{4}{|l|}{$2009[16]$} & \multicolumn{3}{|l|}{41.8} & \multirow[b]{2}{*}{ Post-operation Complications } & \multirow[b]{2}{*}{$9 / 28$} \\
\hline $\begin{array}{l}\text { Batchvarova } \\
\text { Z } \\
2008[17]\end{array}$ & France & $\begin{array}{l}\text { Retrospective } \\
\text { review }\end{array}$ & $52(0 / 52)$ & $39(25-60)$ & $\begin{array}{l}23.5(20- \\
31.5)\end{array}$ & $\begin{array}{l}\text { General } \\
\text { anesthesia }\end{array}$ & & \\
\hline $\begin{array}{l}\text { Dabb RW } \\
\text { 2004[18] }\end{array}$ & USA & Case series & 32 (NR/NR) & NR & NR & $\begin{array}{l}\text { Epidural or } \\
\text { General } \\
\text { anesthesia }\end{array}$ & Post-operation Complications & $6 / 28$ \\
\hline $\begin{array}{l}\text { Nahas FX } \\
\text { 2004[19] }\end{array}$ & Brazil & Case series & $2(0 / 2)$ & $38 \& 59$ & NR & $\begin{array}{l}\text { General } \\
\text { anesthesia }\end{array}$ & $\begin{array}{l}\text { Recurrence rate, } \\
\text { Post-operation Complications }\end{array}$ & $9 / 28$ \\
\hline $\begin{array}{l}\text { Cardenas } \\
\text { Restrepo JC } \\
\text { 2002[20] }\end{array}$ & Columbia & $\begin{array}{l}\text { case-report } \\
\text { series }\end{array}$ & $42(0 / 42)$ & $34(25-53)$ & NR & NR & Post-operation Complications & $7 / 28$ \\
\hline $\begin{array}{l}\text { Ferreira LM } \\
2001[21]\end{array}$ & Brazil & $\begin{array}{l}\text { case-report } \\
\text { series }\end{array}$ & $56(N R / N R)$ & NR & NR & NR & & $8 / 28$ \\
\hline $\begin{array}{l}\text { Nahas FX } \\
\text { 2001[22] }\end{array}$ & Brazil & $\begin{array}{l}\text { Prospective clinical } \\
\text { trial }\end{array}$ & $\begin{array}{l}\text { Intervention } \\
10(\mathrm{NR} / \mathrm{NR})\end{array}$ & $\begin{array}{c}\text { Intervention } \\
38.5\end{array}$ & NR & $\begin{array}{l}\text { General } \\
\text { anesthesia }\end{array}$ & DRAM width $(\mathrm{cm})$ & $16 / 28$ \\
\hline & & & Control & Control & & & & \\
\hline & & & $10(\mathrm{NR} / \mathrm{NR})$ & 32.5 & & & & \\
\hline Nahas FX & Brazil & Case series & $88(0 / 88)$ & $18-59$ & NR & NR & Recurrence rate, & $11 / 28$ \\
\hline $2001[23]$ & & & & & & & Post-operation Complications & \\
\hline van Uchelen & Netherlads & Case series & $63(0 / 63)$ & 39.4 & NR & $\begin{array}{l}\text { General } \\
\text { anesthesia }\end{array}$ & Recurrence rate, & $14 / 28$ \\
\hline $\begin{array}{l}\mathrm{JH} \\
2001[24]\end{array}$ & & & & & & & Post-operation Complications & \\
\hline $\begin{array}{l}\text { Ramirez OM } \\
\text { 2000[25] }\end{array}$ & Baltimore,Md & Case series & $\begin{array}{l}104 \\
(\mathrm{NR} / \mathrm{NR})\end{array}$ & NR & NR & NR & Post-operation Complications & $14 / 28$ \\
\hline $\begin{array}{l}\text { Zukowski ML } \\
\text { 1998[26] }\end{array}$ & USA & Retrospective review & $85(0 / 85)$ & $33(21-50)$ & NR & $\begin{array}{l}\text { General } \\
\text { anesthesia }\end{array}$ & Post-operation Complications & $13 / 28$ \\
\hline $\begin{array}{l}\text { Asaadi M } \\
\text { 1994[27] }\end{array}$ & USA & Case series & 39 (NR/NR) & NR & NR & NR & Post-operation Complications & $8 / 28$ \\
\hline
\end{tabular}

Quality score is based on the Downs and Black criteria. Abbreviations: BMI-Body Mass Index, DRAM-Diastasis rectus abdominus muscel, ELAR-Endoscopic-assisted linea alba reconstruction, ARD-Abdominal rectus diastasis, RD-Rectus abdominus diastasis, IRD-Inter-recti distance, NR-not report.

Table 3 Characteristics of included studies with non-operative intervention. 


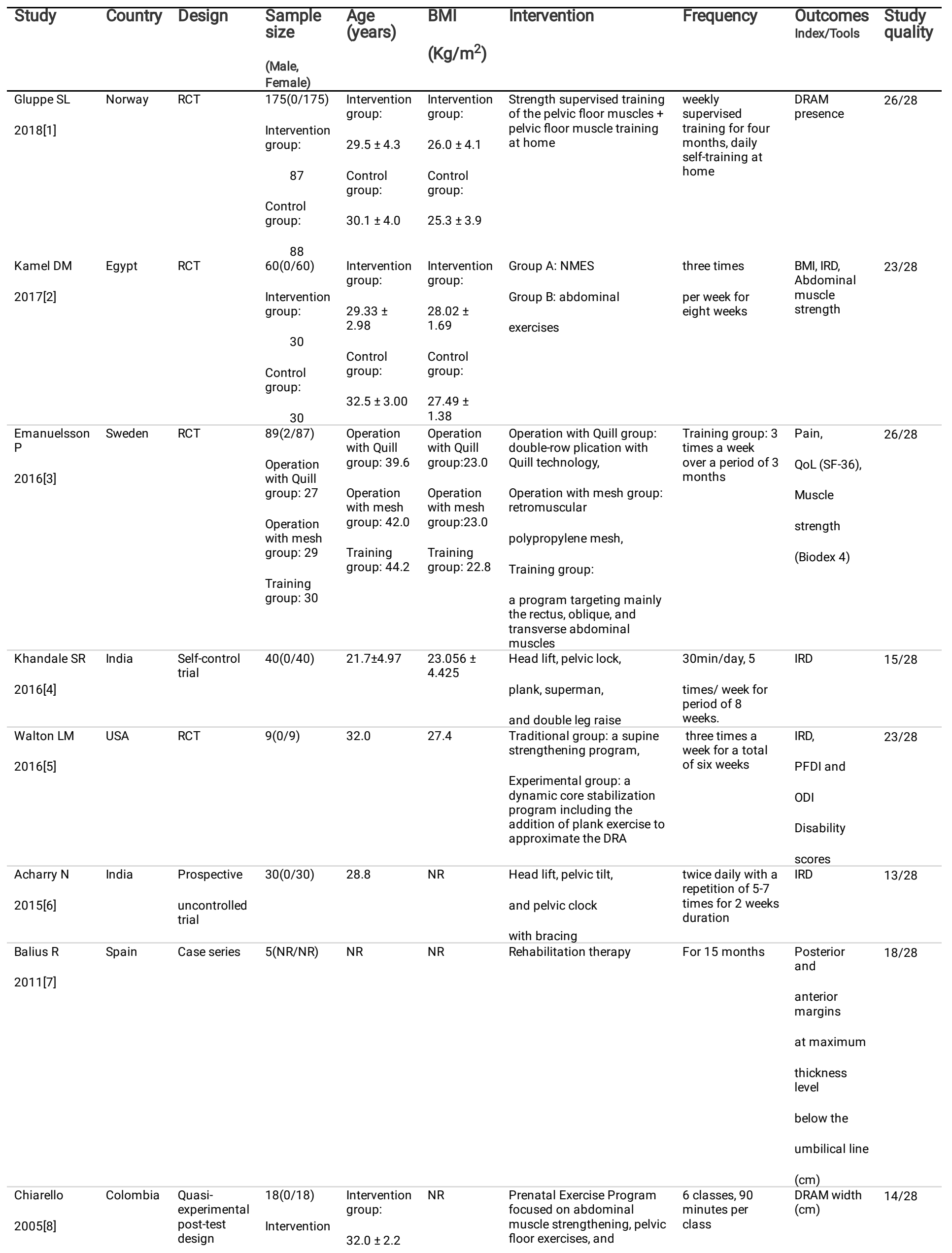




\begin{tabular}{|c|c|c|c|c|c|c|c|c|c|}
\hline & & & $\begin{array}{l}\text { group: } 8 \\
\text { Control } \\
\text { group: } 10\end{array}$ & $\begin{array}{l}\begin{array}{l}\text { Control } \\
\text { group: }\end{array} \\
30.4 \pm 3.95\end{array}$ & & $\begin{array}{l}\text { education in prenatal body } \\
\text { mechanics }\end{array}$ & & & \\
\hline $\begin{array}{l}\text { Hsia M } \\
\text { 2000[9] }\end{array}$ & Australia & Case serious & $\begin{array}{l}2(0 / 2) \\
\text { Subject A: } 1 \\
\text { Subject B: } 1\end{array}$ & $\begin{array}{l}\text { Subject A: } \\
33 \\
\text { Subject B: } \\
28\end{array}$ & $\begin{array}{l}\text { Subject A } \\
24.8 \\
\text { Subject B } \\
23\end{array}$ & $\begin{array}{l}\text { Antenatal fitness } \\
\text { classes from week } \\
30 / 40 \text { to } 39 / 40\end{array}$ & $\begin{array}{l}\text { every Monday, } \\
\text { Wednesday } \\
\text { and Friday over a } \\
\text { maximum period } \\
\text { of } 16 \text { weeks }\end{array}$ & $\begin{array}{l}\text { DRAM width } \\
(\mathrm{cm})\end{array}$ & $14 / 28$ \\
\hline $\begin{array}{l}\text { Sheppard } \\
\text { 1996[10] }\end{array}$ & Japan & Case report & $1(0 / 1)$ & 39 & NR & $\begin{array}{l}\text { Education, tubigrip } \\
\text { and abdominal } \\
\text { exercises postpartum } \\
\text { Postnatal exercise } \\
\text { group at } 5 / 12\end{array}$ & NR & $\begin{array}{l}\text { DRAM } \\
\text { presence (>2 } \\
\text { finger width) } \\
\text { DRAM width } \\
\text { TA } \\
\text { activation } \\
\text { endurance } \\
\text { (hold } \\
\text { seconds) }\end{array}$ & $12 / 28$ \\
\hline
\end{tabular}

Quality score is based on the Downs and Black criteria.

Abbreviations: BMI-Body Mass Index, RCT-Randomized controlled trial, DRAM-Diastasis of recti abdominis muscles, IRD-inter recti distance, NMES- Neuromuscular electrical stimulation, PFDI-Pelvic floor distress index, ODI-Oswestry disability index, QoL- quality of life, NR-not report.

Table 4 Outcomes extracted from included studies with operative intervention 


\begin{tabular}{|c|c|c|c|c|c|c|c|c|}
\hline Study & $\begin{array}{l}\text { Incision } \\
\text { location }\end{array}$ & Endoscopic/mesh/suction & Follow-up & $\begin{array}{l}\text { DRAM } \\
\text { presence }\end{array}$ & $\begin{array}{l}\text { Pain and } \\
\text { Management }\end{array}$ & Recurrence & $\begin{array}{l}\text { Adverse } \\
\text { events }\end{array}$ & $\begin{array}{l}\text { Author } \\
\text { conclusion }\end{array}$ \\
\hline $\begin{array}{l}\text { Juárez Muas } \\
\text { DM 2018[1] }\end{array}$ & $\begin{array}{l}\text { In the } \\
\text { suprapubic } \\
\text { midline. }\end{array}$ & $\mathrm{Y} / \mathrm{Y} / \mathrm{NR}$ & 39 months. & $\begin{array}{l}\text { Diastasis } \\
\text { recti: } \\
<50 \mathrm{~mm} \\
(55.5 \%) \text {; } \\
51 \text { to } 80 \\
\mathrm{~mm} \\
(29.6 \%) \text {; } \\
>81 \mathrm{~mm} \\
(14.9 \%) \text {. }\end{array}$ & $3 / 10$ with VAS. & $\begin{array}{l}0 \% \text { in } 74 \% \\
\text { patients after } \\
18 \text {-months } \\
\text { follow up. }\end{array}$ & $\begin{array}{l}\text { Seroma: } \\
12 \% .\end{array}$ & $\begin{array}{l}\text { Endoscopic } \\
\text { surgery } \\
\text { increasing the } \\
\text { safety of the } \\
\text { repair, without } \\
\text { entering the } \\
\text { abdominal } \\
\text { cavity, with a } \\
\text { short } \\
\text { hospitalization } \\
\text { and no } \\
\text { complications } \\
\text { or recurrence } \\
\text { in } 3 \text { years. }\end{array}$ \\
\hline $\begin{array}{l}\text { Kockerling F } \\
2017[2]\end{array}$ & $\begin{array}{l}\text { Extending } \\
2-3 \mathrm{~cm} \\
\text { cranially in } \\
\text { the } \\
\text { midline. }\end{array}$ & $\mathrm{Y} / \mathrm{Y} / \mathrm{NR}$ & $\begin{array}{l}30 \text { days after } \\
\text { the } \\
\text { operation: } 125 \\
\text { of the } 140 \\
\text { patients; } \\
\text { 1-year follow- } \\
\text { up: } 30 \\
\text { patients. }\end{array}$ & $\begin{array}{l}\text { More than } \\
2 \mathrm{~cm} .\end{array}$ & $\begin{array}{l}30 \text { days after the } \\
\text { operation: } 26 \\
\text { patients ( } 20.8 \%) \\
\text { complained } \\
\text { intermittent pain } \\
\text { in the region of } \\
\text { the mesh } \\
\text { margins, } 7 \text { of } \\
\text { them ( } 5.6 \%) \text { took } \\
\text { painkillers; } \\
1 \text { year later, } 2 \\
\text { patients } \\
\text { complained } \\
\text { occasional pain, } \\
1 \text { of them } \\
\text { complained pain } \\
\text { even at rest. }\end{array}$ & $\begin{array}{l}0 \% \text { after } 1- \\
\text { year follow- } \\
\text { up. }\end{array}$ & $\begin{array}{l}30 \text { days } \\
\text { after the } \\
\text { operation: } \\
\text { discrete } \\
\text { impaired } \\
\text { wound } \\
\text { healing: } \\
1.6 \% ; \\
\text { seroma with } \\
\text { no clinical } \\
\text { significance: } \\
4.8 \% \text {. }\end{array}$ & $\begin{array}{l}\text { ELAR can be } \\
\text { implemented } \\
\text { via a relatively } \\
\text { small open } \\
\text { access route } \\
\text { for the patient } \\
\text { with RAD and } \\
\text { concomitant } \\
\text { umbilical, } \\
\text { trocar, and } \\
\text { epigastric } \\
\text { hernias, so as } \\
\text { to reduce the } \\
\text { complication } \\
\text { rate. }\end{array}$ \\
\hline $\begin{array}{l}\text { Emanuelsson } \\
\text { P 2016[3] }\end{array}$ & NR. & NR/Quill:Y/NR & $\begin{array}{l}1 \text { year after } \\
\text { the operation } \\
\text { and } \\
3 \text { months } \\
\text { after } \\
\text { The training } \\
\text { program. }\end{array}$ & $\begin{array}{l}\text { ARD width } \\
\geq 3 \mathrm{~cm} .\end{array}$ & $\begin{array}{l}\text { VHPQ: operated } \\
\text { and training } \\
\text { group patients } \\
\text { were all } \\
\text { improved. } \\
\text { VAS: sutured } \\
\text { group was } 7 \text {, } \\
\text { mesh repair } \\
\text { group was } 8 \text {, } \\
\text { training group } \\
\text { was } 3 \text {. }\end{array}$ & $\begin{array}{l}1 \text { early } \\
\text { recurrence } \\
\text { occurred in } \\
\text { the Quill } \\
\text { group, } 2 \\
\text { encapsulated } \\
\text { seromas in } \\
\text { the mesh } \\
\text { group, and } 3 \\
\text { seromas in } \\
\text { the suture } \\
\text { group. }\end{array}$ & $\begin{array}{l}\text { Seroma: } 5 \\
\text { patients (3 } \\
\text { with Quill } \\
\text { repair, } 2 \text { with } \\
\text { mesh } \\
\text { repair); } \\
\text { In the } \\
\text { training } \\
\text { group, } 26 \text { of } \\
32 \text { patients } \\
\text { were } \\
\text { dissatisfied } \\
\text { and } \\
\text { discomfort. }\end{array}$ & $\begin{array}{l}\text { There was no } \\
\text { difference } \\
\text { between the } \\
\text { Quill technique } \\
\text { and mesh in } \\
\text { the effect on } \\
\text { abdominal } \\
\text { wall stability, } \\
\text { with a similar } \\
\text { complication } \\
\text { rate. }\end{array}$ \\
\hline
\end{tabular}

\begin{tabular}{|c|c|c|c|c|c|c|c|c|}
\hline $\begin{array}{l}\text { Gallus KM } \\
2016[4]\end{array}$ & $\begin{array}{l}\text { A low transverse } \\
\text { skin }\end{array}$ & NR/NR/NR & NR & NR & NR & NR & NR & $\begin{array}{l}\text { In high functioning military patients with DRA } \\
\text { who fail to return to baseline level of activity } \\
\text { following a trial of physical therapy, surgical } \\
\text { intervention should be considered to obtain } \\
\text { the optimal functional ability. }\end{array}$ \\
\hline $\begin{array}{l}\text { Kockerling } \\
\text { F 2016[5] }\end{array}$ & $\begin{array}{l}\text { On the left side, } \\
\text { encircling the } \\
\text { umbilicus like a } \\
\text { half-loop and } \\
\text { extending } 2-3 \mathrm{~cm} \\
\text { upwards. }\end{array}$ & $\mathrm{Y} / \mathrm{Y} / \mathrm{NR}$ & $\begin{array}{l}\text { A } 30- \\
\text { days } \\
\text { follow- } \\
\text { up. }\end{array}$ & $\begin{array}{l}\text { ARD }<2 \\
\mathrm{~cm} \\
(45 \%)\end{array}$ & $\begin{array}{l}\text { Patients }(7.5 \%) \\
\text { complained of } \\
\text { intermittent pain } \\
\text { on exertion, and } \\
\text { patients (5\%) took } \\
\text { painkillers when } \\
\text { required. }\end{array}$ & $\begin{array}{l}\text { Low } \\
\text { complication } \\
\text { rate in the } \\
\text { early } \\
\text { postoperative } \\
\text { after 30-days } \\
\text { follow-up. }\end{array}$ & $\begin{array}{l}\text { Umbilical } \\
\text { necrosis: } \\
1(2.5 \%) ; \\
\text { Seroma: } 1 \\
(2.5 \%)\end{array}$ & $\begin{array}{l}\text { ELAR plus is a novel minimally invasive } \\
\text { procedure for repair of symptomatic umbilical } \\
\text { and/or epigastric hernias with concomitant } \\
\text { RAD. Reconstruction of the linea alba via a } \\
\text { minimally invasive access route is able to } \\
\text { restore the normal anatomy of the abdominal } \\
\text { wall. }\end{array}$ \\
\hline $\begin{array}{l}\text { Privett BJ } \\
2016[6]\end{array}$ & $\begin{array}{l}\text { A transverse } \\
\text { incision is made } \\
1-2 \mathrm{~cm} \text { superior } \\
\text { to the umbilicus. }\end{array}$ & $\mathrm{N} / \mathrm{Y} / \mathrm{NR}$ & NR & NR & NR & $2(1 \%)$ & $\begin{array}{l}1 \\
\text { superficial } \\
\text { wound }\end{array}$ & $\begin{array}{l}\text { The technique decreased the risk of upper } \\
\text { midline recurrence in the at-risk patient group } \\
\text { and it has a suitably low rate of recurrence } \\
\text { and complications. }\end{array}$ \\
\hline
\end{tabular}




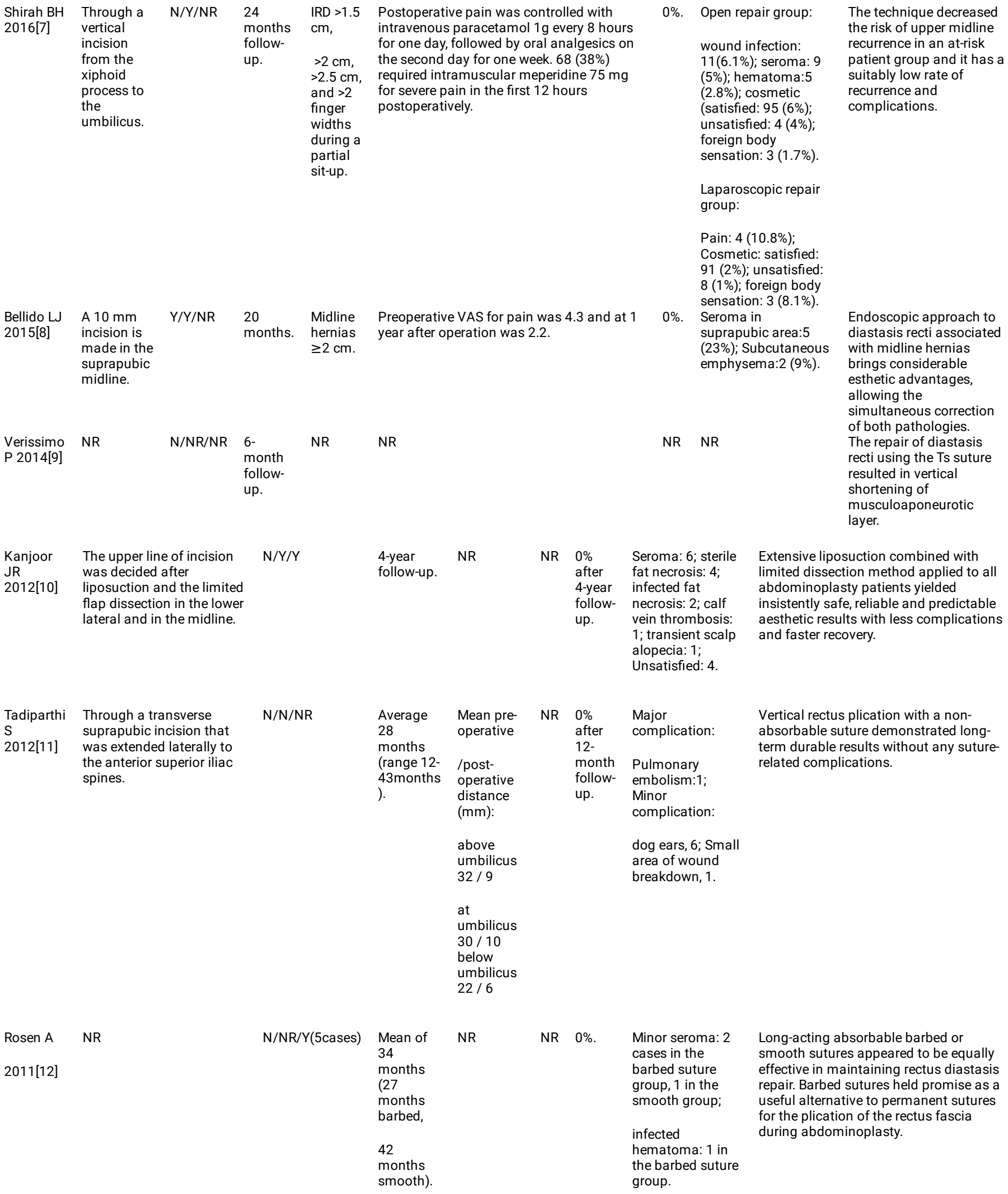


$\begin{array}{ll}\mathrm{N} / \mathrm{NR} / \mathrm{Y} & 3 \text { months NR NR } \\ & \text { to } 2.5 \\ & \text { years. }\end{array}$
NR Umbilical This modified abdominoplasty stenosis: 1 ; technique allows the surgeon to determine the exact pattern of tissue MRSA wound resection at the beginning of the case infection: 1; with a grid marked preoperatively on the patient.

interstitial

hematoma in

the areas

treated by

liposuction:1.

$\begin{array}{ll}\text { Siddiky } & \text { A } 10 \mathrm{~mm} \text { port was placed in the supra- } \\ \mathrm{AH} & \text { pubic region via a modified Hassan } \\ & \text { approach and a } 5 \mathrm{~mm} \text { port was placed }\end{array}$

N/N/NR 8 week

NR Postoperatively

$0 \%$. Pain and

following difficulties in ileus.

discharge pain.

2010[14] in each iliac fossa.

Brauman On the deep abdominal fascia, from one

D flank to the other and from the

2009[15] inframammary crease down (over the rib cage) to the inguinal/pubic crease.

$\begin{array}{lll}N / N R / Y & N R & N R \quad N R\end{array}$
NR Late infections of seromas: $5(1.4 \%)$; marginal necrosis: $6(1.7 \%)$.
Laparoscopic plication was better than open technique, improved recovery time, and reduced pain and wound infection. Furthermore, avoidance of a mesh negates the risks associated with insertion of a foreign body. The enhanced abdominoplasty results and improved safety of the abdominoplasty component enable dramatic body contouring with less morbidity and a fast return to normal activity.
Palanivelu C NR 2009[16]

$\begin{array}{ll}\text { Batchvarova } & \text { Horizontal } \\ \text { Z 2008[17] } & \text { suprapubic } \\ & \text { incision } \\ & \text { extending } \\ & \text { laterally to the } \\ & \text { anterior iliac } \\ & \text { crest. }\end{array}$

Dabb RW

2004[18]

\author{
N/Y/NR Follow up \\ 6-48 \\ months.
}

NR 2 patients experienced pain that lasted for 3 9days: 1 needed intravenous analgesics, while the other was managed with oral analgesics.

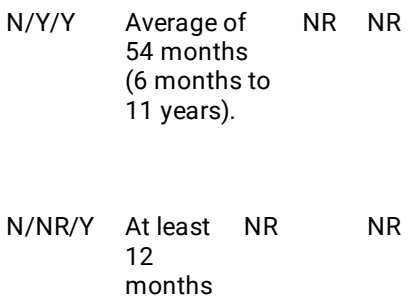

NR

NR NR

\section{$0 \%$ after Pain: 2 \\ 6-48 \\ months Pneumonia: \\ follow 1 \\ up. \\ Chronic \\ pain: 2. \\ NR \\ Seromas: 2; \\ skin flap \\ necrosis: 1 ; \\ umbilical \\ necrosis: 1 . \\ The laparoscopic approach was effective and provided all of the benefits of minimal access in the correction of diastasis. The 'Venetain blinds' technique was an effective form of plication, providing additional support and reducing the risk of seroma. \\ The release and plication of the posterior rectus sheath associated with the use of submuscular resorbable mesh was a long- lasting and reliable procedure in multiparous women with severe myo- aponeurotic laxity.}

NR Seromas: 5;

subdermal burn: 1 ; limited results: 2 .
This technique presented a safe and effective procedure for patients with minimal skin laxity,

moderate fatty tissue distribution, musculofascial diastases, and no concern for abdominal stretch marks.

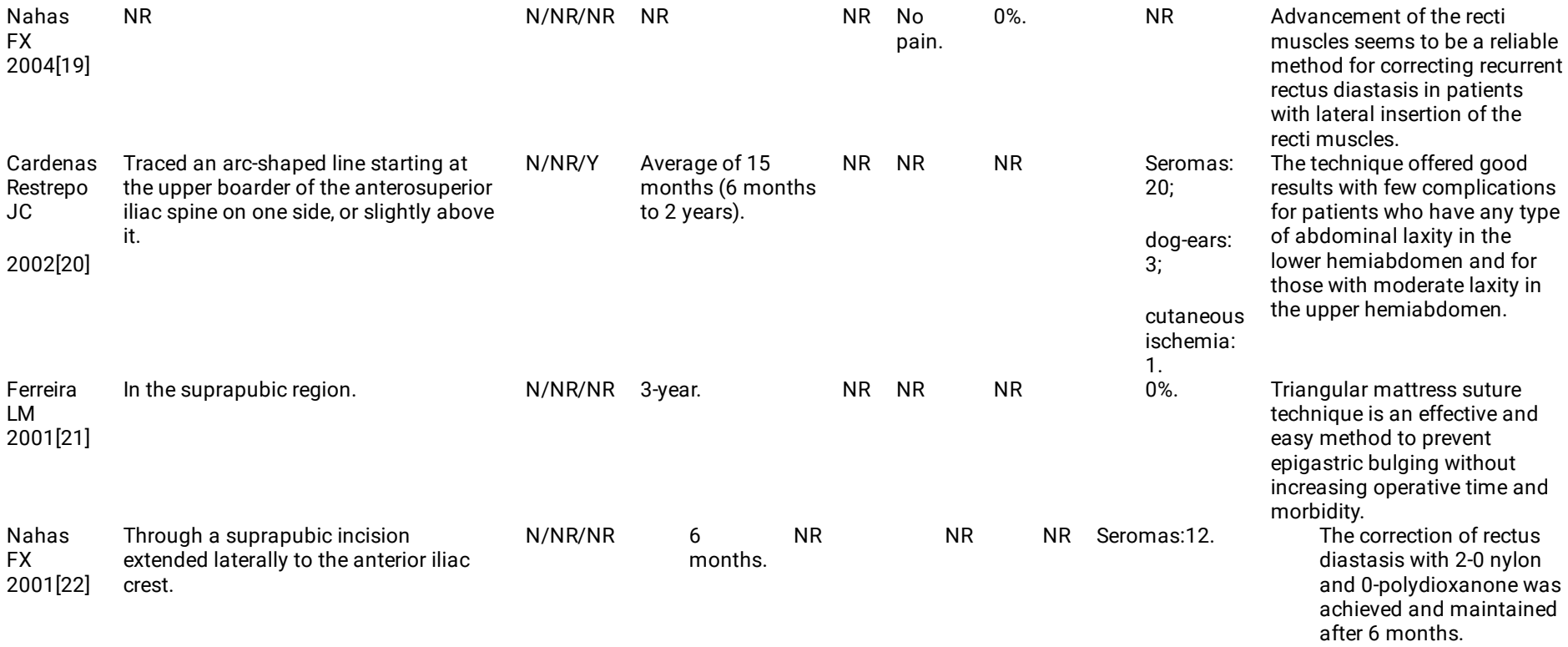



Nahas NR
$\mathrm{FX}$
2001[23]
$\mathrm{N} / \mathrm{NR} / \mathrm{NR}$ At least 3
NR

Minor scar complication: 31 ;

seromas $\square 12$
The classification is a useful

tool to help plastic surgeons to diagnose and treat abdominal deformities, emphasizing correction of the myoaponeurotic layer.

NR $\quad 40 \%$.

$\begin{array}{ll}64 & \text { separation of the } \\ \text { months } & \text { rectus muscles } \\ \text { (32 to } & \text { exceeding } 10 \mathrm{~mm} \\ 109 & \text { above the umbilicus, } \\ \text { months). } & \text { and } 9 \mathrm{~mm} \text { below the }\end{array}$

thrombosis: 1 (1.6\%);

Vertical plication only is not waistline and may eventually sensibility $\begin{array}{ll}\text { van } & \text { A lower abdominal W- } \\ \text { Uchelen } & \text { incision to the aponeurosis }\end{array}$ $\mathrm{JH}$ of the external oblique. 2001[24]

$\begin{array}{ll}\mathrm{N} / \mathrm{NR} / \mathrm{NR} & \text { Mean of } \\ & 64 \\ & \text { months } \\ & \text { (32 to } \\ 109 \\ \text { months). }\end{array}$

umbilicus;

$\geq 45$ years old:

the corresponding values were $15 \mathrm{~mm}$ $27 \mathrm{~mm}$, and $14 \mathrm{~mm}$.

N/NR/Y NR NR

$\begin{array}{lllll}\text { Ramirez } & \text { An incision in a navel is } & \text { N/NR/Y } & \text { NR } & \text { NR } \\ \text { OM } & \text { made in a heart shape with a } & & & \\ 2000[25] & \text { triangular component left in } \\ \text { the abdominal flap in a } \\ \text { superior or inferior } \\ \text { orientation. }\end{array}$

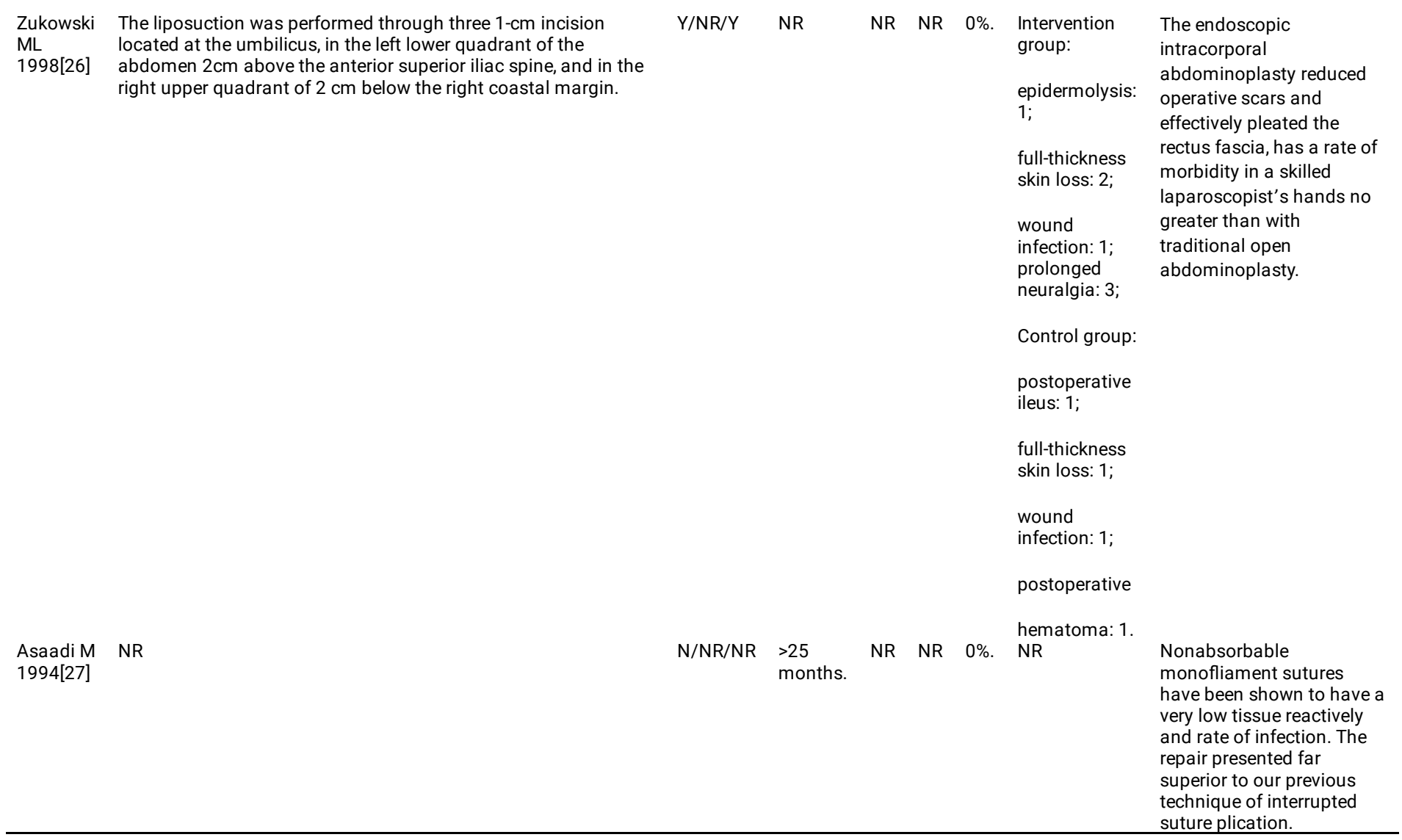

Abbreviations: BMI-Body Mass Index, DRAM-Diastasis rectus abdominus muscel, ELAR-Endoscopic-assisted linea alba reconstruction, ARD-Abdominal rectus diastasis,
The new technique: a combination of suctionassisted lipectomy, high lateral tension closure with fascial suspension and external oblique fascial advancement to create a smaller waistline can provide predictable, reproducible, and aesthetically pleasing results. relieved
postoperatively.

Skin necrosis: 3 ;

seroma: 5. abdominal skin:

$45(71.4 \%)$

sensibility disorder of the thigh: 6 


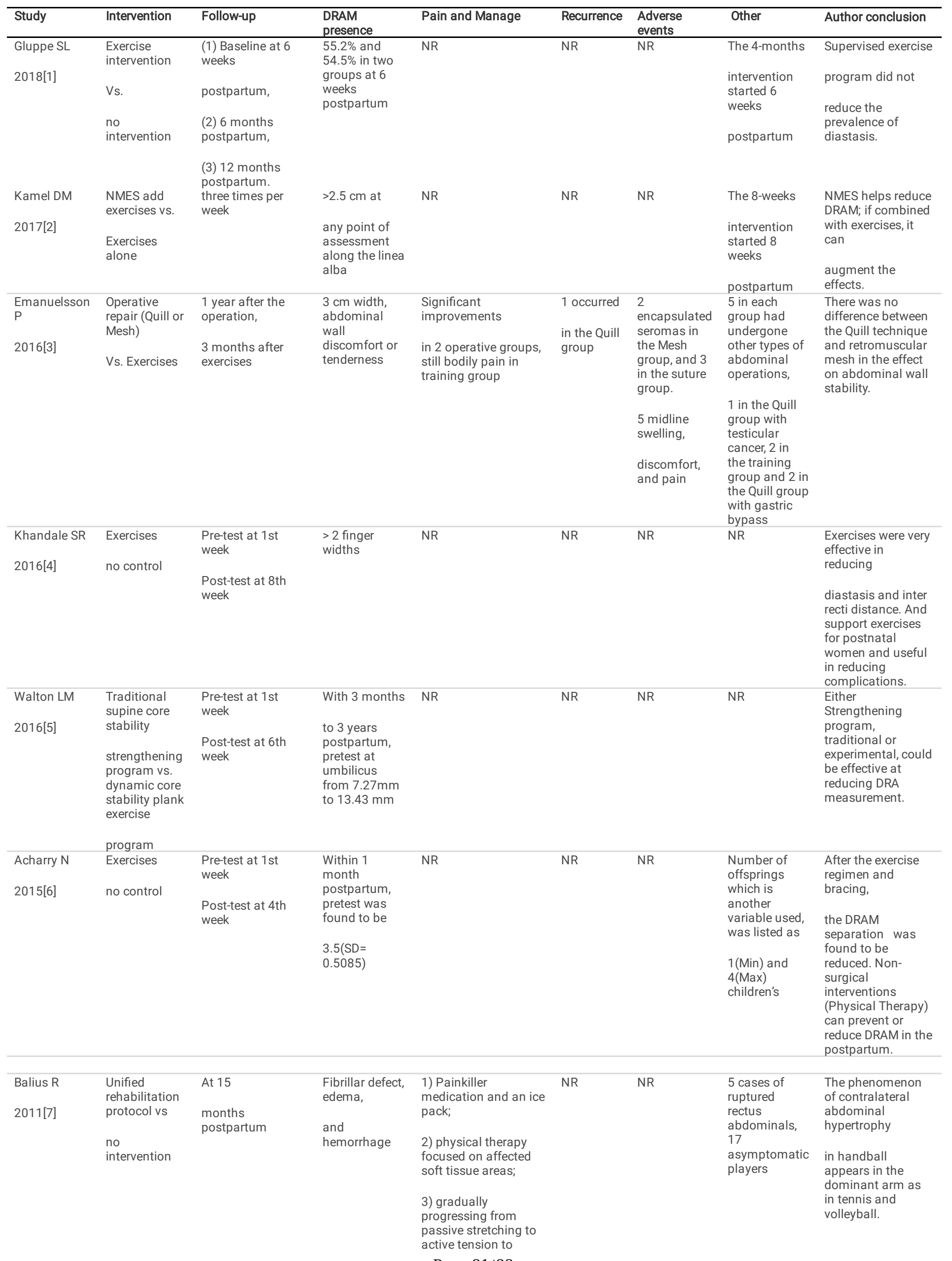

Page 21/23 


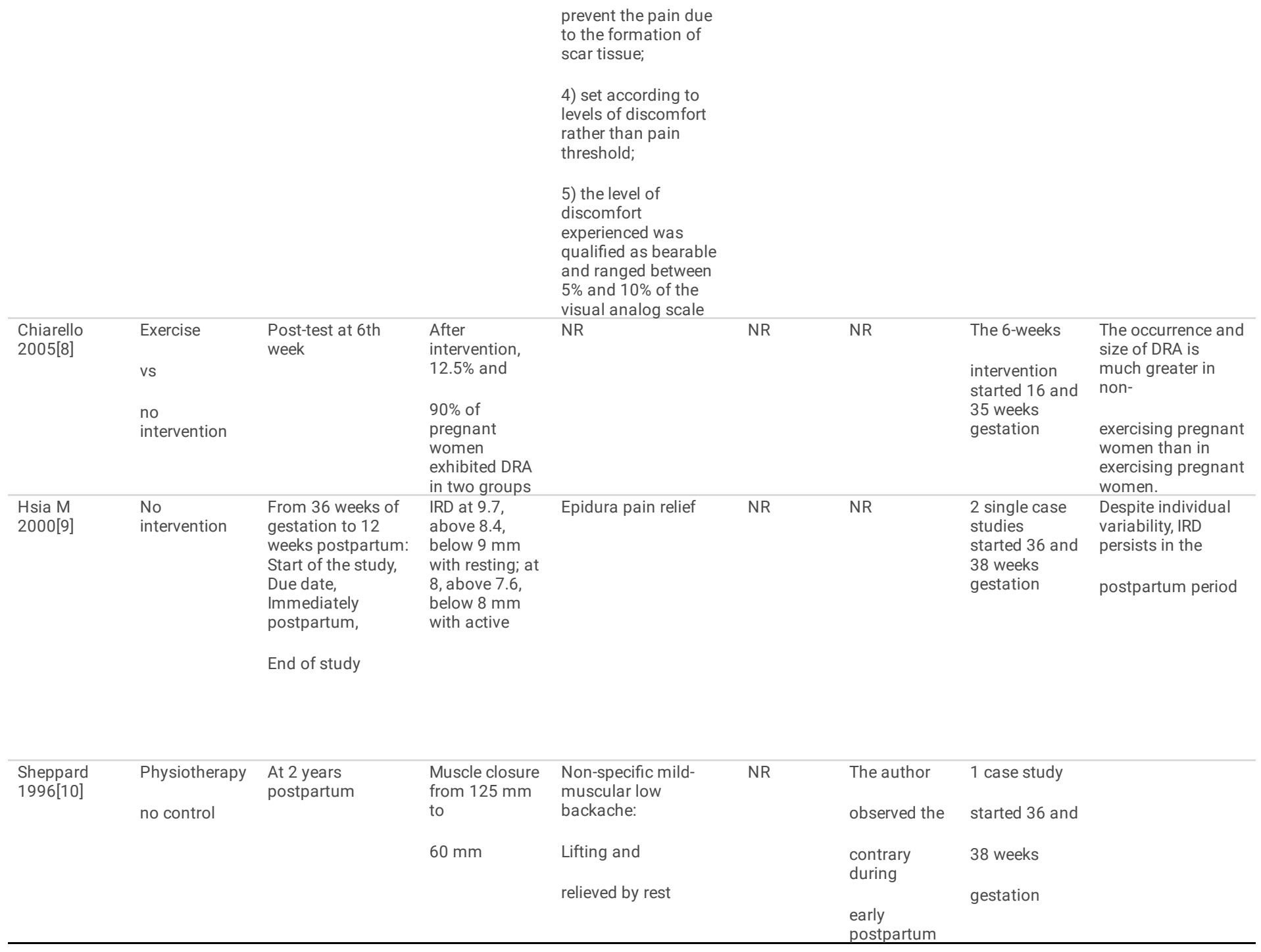

Abbreviations: DRAM-Diastasis rectus abdominus muscel, ELAR-Endoscopic-assisted linea alba reconstruction, ARD-Abdominal rectus diastasis,

RD-Rectus abdominus diastasis, IRD-Inter-recti distance, VAS-Visual analogical scale, VHPQ-Ventral hernia pain question-naire, NR-not report.

Figures

Fig. 1 The comparison of hernia recurrence rate after repair procedure with mesh

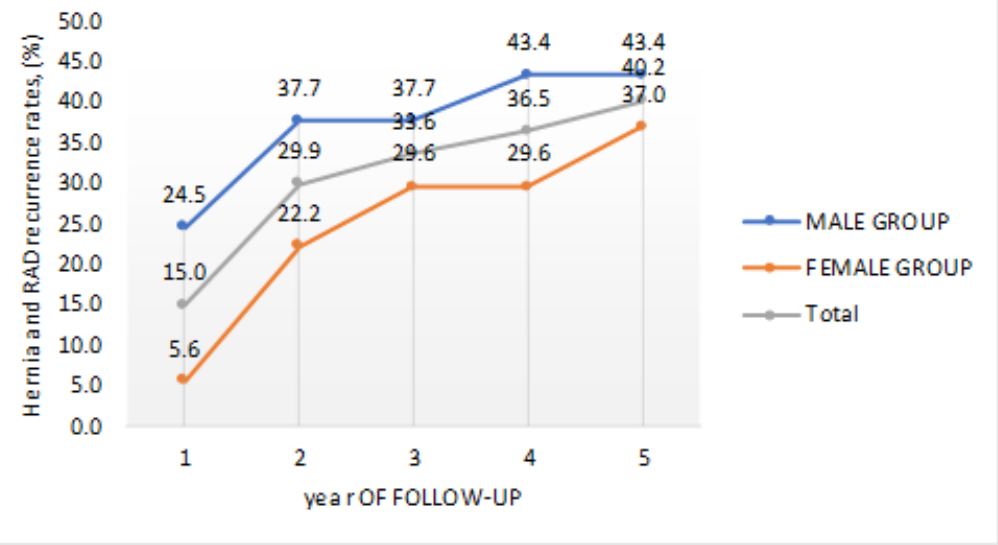

Figure 1

Page 22/23 
The comparison of hernia recurrence rate after repair procedure with mesh.

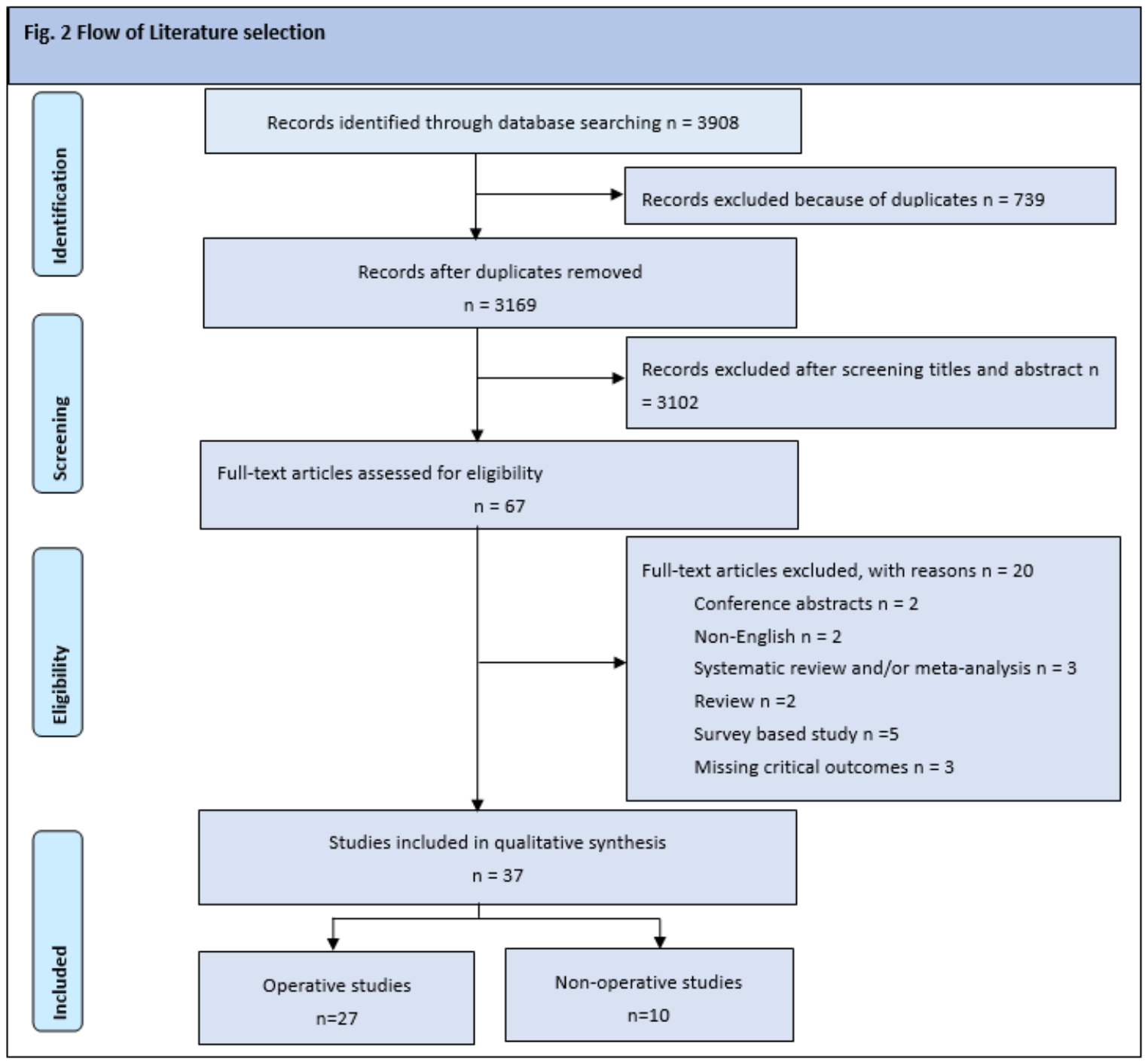

Figure 2

Flow of Literature selection.

\section{Supplementary Files}

This is a list of supplementary files associated with this preprint. Click to download.

- SupplementalFile1.pdf

- SupplementalFile2.pdf 